\title{
Pengembangan Media Carier Box dalam Bimbingan Kelompok untuk Pengenalan Karir di PAUD
}

\author{
Mimbar Oktaviana ${ }^{1}$, Sriyanti ${ }^{2}$, \\ ${ }^{1}$ Pendidikan Islam Anak Usia Dini, Sekolah Tinggi Ilmu Tarbiyah Muhammadiyah Bojonegoro \\ ${ }^{2}$ Pendidikan Islam Anak Usia Dini, Sekolah Tinggi Ilmu Tarbiyah Muhammadiyah Bojonegoro \\ e-mail:oktavianamimbar@gmail.com
}

\begin{abstract}
Abstrak: Penggunaan media pembelajaran pada proses belajar mengajar pada jenjang PAUD sangat membantu untuk meningkatkan pemahaman siswa. Penelitian ini didasarkan pada kurang bervariasinya media pembelajaran yang digunakan pada jenjang PAUD khususnya dalam pengenalan karir. Penggunaan media yang slama ini digunakan hanya memfungsikan indra penglihatan dan pendengaran siswa sehingga membuat penyampaian materi ke siswa hanya sebesar $10 \%$. Berdasarkan hal tersebut maka perlu adanya media yang bisa meningkatkan aktifitas pembelajaran dengan memberikan siswa pengalaman tiruan. Media tersebut adalah media carier box yang dapat dilaksanakan dalam bimbinan kelompok. Tujuan dari peneitian ini adalah membuat media pembelajaran yang menyenangkan dan dapat memaksimalkan penyampaian materi kepada siswa, sehingga siswa bisa lebih mengenal tentang macam-macam jenis pekerjaan. Penelitian ini menggunakan model pengembangan Borg \& Gall dengan 4 tahap yaitu analisis produk, pengembangan produk awal, validasi ahli dan revisi, uji coba lapangan skala kecil dan revisi produk Hasil penelitian didapat dari hasil uji validitas dari ahli materi, ahli media, ahli praktisi yang kemudian diolah menjadi persentase. Dari hasil uji coba ahli dengan ahli materi diperoleh rerata persentase sebesar $89,2 \%$, hasil ahli media mencapai $81,5 \%$. Kemudian juga dari hasil uji coba skala kecil dengan meminta menilaian dua orang praktisi diperoleh rerata sebesar $89,12 \%$ dan $88,55 \%$. Selanjutnya rata rata dari semua presentase hasil validasi adalah $87,09 \%$. Setelah mendapatkan data tersebut dihasilkan pula data kualitatif bahwa media carier box termasuk dalam kategori sangat baik dan sesuai dengan kriteria kelayakan sehingga dapat digunakan sebagai salah satu media pembelajaran dalam bimbingan kelompok di jenjang PAUD
\end{abstract}

Kata kunci: Bimbingan kelompok, media pembelajaran, pengenalan karir

\section{PENDAHULUAN}

Anak usia dini adalah anak yang berada pada rentan usia 0-6 tahun ${ }^{1}$. Berdasarkan penelitian daari Osborn, White dan Bloom menunjukkan hasil studi pada bidang neurologi bahwa perkembangan kogintif anak ketika berumur 4 tahun telah mencapai 50\%, berkembang hingga $80 \%$ ketika anak berumur 8 tahun dan akan mencapai perkembangan maksimal $100 \%$ di umur $18 \operatorname{tahun}^{2}$. Pada usia ini anak mengalami masa pertumbuhan dan perkembangan yang pesat dimana perkembangan otak manusia berkembang hingga $80 \%$ sehingga disebut sebagai masa keemasan atau golden age. Stimulasi yang diberikan pada usia ini memiliki peran besar terhadap pola pikir dan

\footnotetext{
${ }^{1}$ Undang-undang RI No.20 tahun 2003 Tentang sistem pendidikan nasional 2003

${ }^{2}$ Gutama. Pendidikan Karakter Pada Anak Usia Dini. (Perpustakaan Kemendiknas.go.id)
} 
pemahaman anak yang akan dibawa hingga tahap perkembangan berikutnya. Locke percaya bahwa pengalaman masa anak-anak sangat menentukan karakteristik seseorang ketika dewasa. ${ }^{3}$

Pengalaman yang dialami oleh anak akan memberikan sensasi tersendiri karena akan memberikan sensasi yang tidak dapat dilupakan. Pengalaman ini bisa digunakan sebagai salah satu metode pembelajaran pada anak usia dini agar materi yang diberikan lebih mudah dipahami dan diingat oleh anak. Menurut Edgar Dale dalam teorinya Cone of Experience (Dale, 1969) menjelaskan bahwa tingkat ingatan seseorang yang paling tinggi yaitu sebesar $90 \%$ jika proses pembelajaran dilakukan dengan tindakan. ${ }^{4}$ Pada tahap aktivitas pembelajaran ini individu dapat melakukan analisis, menciptakan hal baru dan melakukan evaluasi. Hal ini akan berdampak berbeda jika anak hanya mendapatkan aktifitas pengalaman belajar dengan memanfaatkan indera penglihatan dan pendengaran, daya ingat hanya sebesar $10 \%$ hingga $20 \%$. Hal ini menunjukkan bahwa ingatan anak tentang pembelajaran akan lebih lama bertahan apabila dilakukan dengan mengikutsertakan semua alat indera atau pengalaman langsung.

Upaya peningkatan kemampuan pada tahap anak usia dini berorientasi pada kegiatan bermain, hal ini dilatarbelakangi oleh tingkat konsentrasi yang sangat singkat yaitu antara 10-15 menit. Oleh karena itu dalam proses belajar mengajar pada jenjang pendidikan anak usia dini dirancang secara khusus melalui metode bermain sambil belajar, karena dapat meningkatkan daya konsentrasi anak yang lebih lama. Hasil penelitian menunjukkan bahwa pembelajara dengan metode bermain mampu meningkatkan konsentrasi belajar anak engan kriteria keberhasilan sebesar $75 \%{ }^{5}$ Hasil penelitian lain juga menunjukkan bahwa model bimbingan kelompok dengan teknik bermain peran efektif meningkatkan interaksi sosial siswa. ${ }^{6}$ Pada tahap perkembangan anak usia dini, anak memiliki rasa ingin anak akan lebih banyak belajar dari kegiatan sehari-hari seperti bermain. Piaget menyatakan bahwa permainan merupakan salah satu media yang bisa diunakan untuk meningkatkan perkembangan kognitif individu. ${ }^{7}$ Hal yang serupa juga dinyatakan oleh Vygotsky bahwa permainan adalah suatu setting yang sangat sesuai untuk meningkatkan perkembangan kognitif individu. ${ }^{8}$ Berdasarkan hal ini media permainan sangat sesuai digunakan dalam proses belajar mengajar di jenjang PAUD untuk meningkatkan kemampuan kognitif anak.

Untuk memaksimalkan perkembangan anak PAUD Alam ABA 2 Bojonegoro juga menggunakan media pembelajaran sebagai penunjuang dalam proses belajar mengajar, akan tetai

\footnotetext{
3 Jhon W. Santrock, Child Development, (Boston:Pearson Education, 2010)

${ }^{4}$ Edgar Dale, Audio Visual Methods in Theaching, (New York:Holt,Rinehart and Winston Inc.The Dryden Press, 1969)

5 Apri Ratnayanti, 2018, Peningkatan Konsentrasi Beajar Anak Melalui Bermain Lempar Tangkap Bola Pada Anak Kelompok B TK Negeri Pembina Gelumbang:Sumatera Selatan, Fakultas Keguruan dan Ilmu Pendidikan Universitas Sriwijaya

${ }^{6}$ Novi Andriati, 2016, Model Bimbinan Kelompok Dengan Teknik Bermain Peran Untuk Meningkatkan Interaksi Sosial Siswa:Pontianak, Bimbingan dan Konseling IKIP PGRI Pontianak

${ }^{7}$ John Piaget, The Origins of Intelligence in Children,(New York: International Universities Press, 1952)

${ }^{8}$ LS Vygotsky, Mind in Society: The Development of Higher Psychological Processes, Ed. Michael Cole et.al (Cambridge:Harvard University Press, 1987)
} 
masih terdapat kendala yang dialami saat prosesbelajar mengajar berlangsung. Berdasarkan hasil wawancara yang dilakukan dengan pada tenaga pendidik diketahui bahwa: 1) media yang digunakan dalam proses belajar mengajar masih terbatas untuk klasikal seperti kartu dan gambar atau posterposter di dinding kelas, 2) media yang digunakan lebih dominan pada media pembelajaran individu, 3) media pengenalan karir yang terbatas. masalah lain juga terlihat saat peneliti melakukan observasi selama proses belajar mengajar berlangsung yaitu: 1) dalam proses belajar megajar klasikal siswa kurang mendapat perhatian dan pemahaman karena jumlah siswa yang banyak, 2) tingkat konsentrasi anak yang tidak bertahan lama sehingga anak lebih banyak bermain sendiri dengan temannya daripada memperhatikan guru, 3) jumlah guru dan siswa yang tidak seimbang saat proses pembelajaran menggunakan media pembelajaran individu sehingga, banyak anak yang kurang terlayani dengan baik dalam proses belajar mengajar. Selain itu guru membutuhkan media pembelajaran yang berisi tentang jeni-jenis karir yang bermacam-macam sehingga bisa membuka wawasan siswa tentang karir. Media pembelajaran yang berorientasi pada belajar sambil bermain juga diperlukan untuk menarik minat siswa dalam mengikuti proses belaja mengajar.

Wawancara kedua dilakukan peneliti untuk mendapatkan informasi tentang usaha yang telah dilakuakan untuk mengatasi permasalah-permasalah tersebut. Berdasarkan hasil wawancara ini dikemukakan bahwa guru di PAUD Alam ABA 2 Bojonegoro tidak bisa berbuat banyak untuk menangani masalah-masalah tersebut karena faktor keterbatasan media yang ada, guru juga berharap ada media pembelajaran yang bisa digunakan secara berkelompok sehingga dapat membantu siswa dalam pemahaman materi pengenalan karir.

Hasil wawancara dan observasi yang dilakukan oleh peneliti tentang permasalahan yang ada, maka diperlukan adanya pengembangan media pembelajaran untuk menangani masalah keterbatasaan media yang ada. Media yang dikembangkan akan diterapkan dalam bimbingan kelompok untuk meningkatkan pemahaman dan layanan kepada siswa. Untuk meningkatkan konsentrasi anak maka media ini akan dimainkan siswa dengan metode bermain yang memfungsikan semua alat indera, diharapkan media ini bisa memberikan pengalaman langsung kepada siswa dan materi yang disampaikan akan lebih diingat oleh siswa. Media pembelajaran ini adalah media carier box yang diadopsi dari permainan ular tangga dengna diberikan beberapa penyesuaian sesua dengan kebutuhan dan tujuan media pembelajaran.

Pengertian tentang pengenalan jenis-jenis karir digunakan sebagai landasan dasar dalam menyusun materi pada media carier box, dengan adanya pengenalan tentang berbagai jenis karir diharapkan siswa menjadi memiliki banyak gambaran citacita untuk asa depannya. Pengembangan merupakan suatu proses untuk mengembangkan produk-produk yang sudah ada untuk dapat 
dimaksimalkan keggunaannya sesuai dengan ujuan tertentu. ${ }^{9}$ Bimbingan kelompok digunakan sebagai sarana untuk menyampaikan pesan atau materi yang diharapkan dapat meningkatkan efektifitas proses belajar mengajar yang lebih aktif. ${ }^{10}$ Permainan digunakan sebagai metode penyampaian materi yang menyenangkan sehingga dapat membat siswa menjadi lebih mudah dalam memahami materi yang disampaikan. ${ }^{11}$

Berdasarkan latar belakang permasalahan yan sudah dirumuskan, peneliti melakukan pengembangan media yang bertujuan unutk menghasilkan produk media pembelajaran dalam bimbingan kelompok untuk meningkatkan pengenalan karir pada jenjang pendidikan PAUD. Media yang akan dikembangkan oleh peneliti adalah media carier box yang telah memenuhi uji kelayakan dan bisa diharapkan bisa digunakan dalam skala besar.

\section{METODE}

Jenis penelitian yang digunakan adalah jenis penelitian pengembangan yang dikemukakan oleh Borg and Gall yang kemudian disederhanakan oleh Tim puslitjaknov tahun 2008 menjadi 5 langkah pengembangan sebagai berikut $\left.{ }^{12}: 1\right)$ Analisis awal produk, 2) Pengembangan produk awal, 3) Validasi ahli dan revisi, 4) uji lapangan skala kecil dan revisi produk, 5) uji coba lapangan skala besar dan produk akhir. Sebagai salah satu keterbatasan dalam penelitian ini tahap pengembangan pada penelitian ini dilakukan hanya sampai pada tahap ke 4 dari 5 langkah pengembangan yang seharusnya.

Teknik pengumpul data pada penelitian ini menggunakan observasi, wawancara dan studi kepustakaan dengan menggunakan kuesioner. Analisis data dalam penelitian ini terdiri dari analisis kualitatif dan kuantitatif. Analisis data diperoleh dari angket tertutup dengan melakukan scoring berupa rating scale sebagai berikut $:^{13}$

Tabel 1. Scoring rating score

\begin{tabular}{lll}
\hline No. & Score & Kategori \\
\hline 1 & 4 & Sangat baik \\
2 & 3 & Baik \\
3 & 2 & Kurang Baik \\
4 & 1 & Tidak Baik \\
\hline
\end{tabular}

\footnotetext{
9 Juni Purnamasari, 2015, Pengembangan Media Permainan “Career's Adventure” Dalam Bimbingan Kelompok Untuk Siswa Kelas XI SMAN Nglames Madiun:Surabaya, BK FIP Universitas Negeri Surabaya

${ }^{10}$ Juni Purnamasari, 2015, Pengembangan Media Permainan "Career's Adventure” Dalam Bimbingan Kelompok Untuk Siswa Kelas XI SMAN Nglames Madiun:Surabaya, BK FIP Universitas Negeri Surabaya

${ }^{11}$ Juni Purnamasari, 2015, Pengembangan Media Permainan "Career's Adventure” Dalam Bimbingan Kelompok Untuk Siswa Kelas XI SMAN Nglames Madiun:Surabaya, BK FIP Universitas Negeri Surabaya

${ }_{12}$ Tim Puslitjaknov, Metode Penelitian Pengembangan (Jakarta:Pusat Penelitian Kebijakan dan Inovasi Pendidikan Badan Penelitian dan Departemen Pendidikan Nasional, 2008)

${ }^{13}$ Sudijono, Pengantar Statistik Pendidikan (Jakarta:Raja Grafindo Persada,2008)
} 
Subjek penelitian ini adala siswa di PAUD Alam ABA 2 Bojonegoro yang memiliki indikasi mengalami kesulitan dalam pengenalan karir. Pada tahap pertama yaitu analisis awal produk, peneliti melakukan penyebaran instrumen analisis kebutuhan kepada guru pengajar di PAUD Alam ABA 2 Bojonegoro untuk digunakan sebagai landasan dalam pembuatan isi atau materi dalam media yang akan dikembangkan. Pada tahap pengembangan produk awal, peneliti membuat desain dasar media yang nantinya akan dikembangkan sesuai dengan kebutuhan subjek. Tahap ketiga atau tahap validasi ahli, peneliti menggunakan satu ahli materi dan satu ahli media dalam menyusun materi dan desain media carier box. Selanjutnya pada uji coba lapangan, peneliti mengguanakan dua orang praktisi dan 6 pengguna/siswa

\section{HASIL DAN PEMBAHASAN}

\section{A. Pra Pengembangan}

\section{Analisis Produk}

Analisis produk dilakukan dengan mengumpukan 2 sumber data yaitu dari studi lapangan dengan menyebarkan instrumen kuesioner untuk melihat fakta yang terjadi dilapangan dan juga kebutuhan lapangan dan studi kepustakaan untuk memperoleh sumber materi dalam penyusunan pembuatan media carier box yang sesuai engan kebutuhan di lapangan. Berdasarkan dari hasil lapangan diketahui bahwa siswa PAUD Alam ABA 2 Bojonegoro memiliki pengetahuan yang minim tentang jenis-jenis pekerjaan sehingga berdampak pada $85 \%$ siswa memiliki cita-cita untuk bekerja seperti orang tuanya. Selain itu, dalam proses pengenalan jenis-jenis pekerjaan guru hanya menggunakan metode ceramah dan media kartu/gambar sehingga siswa masih belum bisa memiliki gambaran yang utuh tentang jenis-jenis pekerjaan. Hasil wawancara juga menunjukkan bahwa media pembelajaran yang dimiliki dalam pengenalan jenis-jenis pekerjaan masih terbatas sehingga sulit untuk menarik minat siswa agar mau belajar lebih dalam lagi.

\section{B. Pengembangan}

\section{Pengembangan produk awal}

Media carier box merupakan media permainan yang didalamnya terdapat unsur gambar dan teks yang termasuk dalam klasifikasi media permainan dan simulasi serta penerapannya secara kelompok. Carier box ini terdiri dari buku panduan, dadu dan papan permainan. Buku panduan berisi tentang aturan permainan, dan tata cara permainan, dadu berisi tentang jumlah langkah yang akan di jalankan oleh setiap pemai, papan permainan berisi dengan 25 kotak dengan berbagai macam jenis-jenis pekerjaan

Media carier box ini dibuat oleh peneliti dengan mengadopsi istem permainan ular tangga dengan mengganti beberapa point-pointnya menjadi jenis-jenis pekerjaan. Media carier box dibuat dengan mengguanakan aplikasi corel draw untuk papan permainannya dan microsoft 
word untuk buku panduannya. Selama proses pengembangan media berlangsung terjadi media carier box telah melakukan uji validasi dan mengalami beberapa revisi. Berikut adalah beberapa revisi yang sudah dikembangkan oleh peneliti setelah melalui uji validasi :

a. Buku panduan

Buku panduan carier box dicetak dengan menggunakan kertas A5 dengan softcover berwarna kuning dan hijau. Buku panduan ini berisi tentang aturan permainan carier box, tata cara permainan carier box, penjelasan jenis-jenis pekerjaan yang ada pada papan permianan. Buku panduan ini diharapkan dapat mempermudah guru dalam pengguanan media.

b. Dadu

Dadu ini berbahan plastik berbentuk kotak seperti balon dengan permukaan yang menyerupa dadu, dadu ini digunakan siswa dengan cara dilempar untuk menentukan jumlah langkah yang akan dilakukan oleh siswa.

c. Papan permainan

Papan permainan ini dicetak dalam bentuk banner dengan ukuran 2 × 2 meter dengan berisikan 25 kotak dengan gambar jenis-jenis pekerjaan yang berbeda-beda.

\section{Validasi ahli dan Lapangan}

Media carier box yang telah direvisi akan dilanjutkan pada tahap uji validasi. Uji validasi dilakukan dengan membawa media kepada ahli yang sudah ditentukan sebelumnya untuk dinilai dengn memberikan kritik dan saran. Uji validasi tersebut antara lain satu orang ahli materi yang memiliki keahlian di bidang materi jenis-jenis pekerjaan, satu orang ahli media yang memiliki keahlian khusus di bidang desain dan tekhnologi, dua orang praktis yang memiliki kualifikasi sebagai guru pengajar di PAUD.

Pada tahap ini ahli media memberikan revisi berupa desain yang lebih simpel agar penggunaa lebih mudah untuk memahaminya. Setelah dilakukan revisi kemudian media dibawa kembali kepada ahli untuk ditinjau ulang hingga pada tahap media cukup yang bisa dilanjukan ke uji laangan skala kecil.

Hasil Uji Praktisi diperoleh masukan berupa gambar jenis-jenis pekerjaan diharapkan agar lebih besar sehingga siswa bisa lebih jelas dalam melihat gambar tersebut. Untuk buku panduan revisi praktisi hampir sama dengan ahli media yaitu tentang penggunaan desain yang lebih simpel.

Masukan dan saran yang diberikan saat validasi ahli digunakan peneliti sebagai salah satu bahan penilaian kualitatif media carier box. Penilaian kuantitatif dari media carier box ini 
diperoleh berdasarkan hasil kuesioner yang dibagikan kepada para ahli dan praktisi yang berupa nilai persentase dan kategori persentase ini akan digunakan sebagai penilaian kualitatif secara keseluruhan.

Berdasarkan hasil yang telah disebutkan diatas diperoleh nilai sebesar $89,2 \%$ dari ahli materi, $81,5 \%$ dari ahli media dan $89,12 \%$ serta $88,55 \%$ dari dua praktisi. Sehinggan dapat diperoleh rerata nilai keseluruhan sebesar 87,09\% hasil ini kemudian dikategorikan berdasarkan kriteria penilaian menurut Mustaji (2005:102) yang menunjukkan bahwa media carier box termasuk dalam kategori sangat baik (81\%-100\%) sehingga untuk tidak diperlukan revisi

\section{SIMPULAN}

Kesimpulan dari pengembangan media carier box menunjukkan bahwa media ini telah memenuhi kriteria kelayakan sebagai media pengenalan karir untuk diberikan pada jenjang pendidikan PAUD dalam proses beajar mengajar. Hasil ini diperoleh dari hasil uji validasi ahli materi dengan nilai sebesar $89,2 \%$, nilai dari uji validsi ahli media sebesar $81,5 \%$, nilai dari dua uji lapangan skala kecil yaitu sebesar $89,12 \%$ dan $88,55 \%$. Secara keseluruhan media carier box ini mendapatkan nilai sebesar $87,09 \%$ yang masuk dalam kategori sangat baik (81\%-100\%) sehingga untuk tidak diperlukan revisi. Media ini diharapkan dapat meningkatkan pemahaman siswa PAUD dalam pengenalan materi-materi karir serta dapat membantu para praktisi dalam penyampaian materi pengenalan karir dalam proses belajar mengajar.

\section{DAFTAR RUJUKAN}

Andriati, Novi. Model Bimbingan Kelompok Dengan Teknik Bermain Peran Untuk Meningkatkan Interaksi Sosial Siswa. Bimbingan dan Konseling IKIP PGRI Pontianak (Jurnal Konseling GUSJIGANG Vol. 2 No. 2 (Juli-Desember 2016) Print ISSN 2460-1187, Online ISSN 2503-281X)

Dale, Edgar, (1969) Audio Visual Methods in Teaching, New York: Holt, Rinehart and Winston Inc. The Dryden Press.

Depdiknas .2003. Undang-undang RI No.20 tahun 2003.tentang sistem pendidikan nasional

Penelitian Osborn, White, dan Bloom dalam Gutama, "Pendidikan Karakter Pada Anak Usia Dini”, dalam Perpustakaan Kemendiknas.go.id

Piaget, J. The Origins of Intelligence in children, Trans. M. Cook, Trans, New York International Universities Press, 1952

Puslitjaknov, Tim. 2008. Metode Penelitian Pengembangan. Jakarta : Pusat Penelitian Kebijakan dan Inovasi Pendidikan Badan Penelitian dan Departemen Pendidikan Nasional. 
Ratnayanti, Apri. Peningkatan Konsentrasi Belajar Anak Melalui Bermain Lempar Tangkap Bola Pada Anak Kelompok B Tk Negeri Pembina Gelumbang. Fakultas Keguruan dan Ilmu Pendidikan Universitas Sriwijaya. 2018

Santrock, Jhon W., Child Development, Boston: Pearson Education, 2010

Santrock, Jhon W., Child Development, Terj. Mila Rachmawati dan Anna Kuswanti, Perkembangan Anak Jilid 1, Jakarta: Erlangga, 2007

Santrock, Jhon W., Educational Psychology, 5th edition, New York: McGrawHill Companies, 2011

Santrock, Jhon W., Life-Span Development, C. Brown Communication, 1995

Sudijono, A. (2008). Pengantar Statistik Pendidikan. Jakarta: raja grafindo persada

Vygotsky, LS, "Emotions and their Development in Childhood" dalam R. Rieber (Ed.), The Collected Works of L. S. Vygotsky. Vol. 1 (hh. 325-337), New York: Plenum Press. 1987

Vygotsky, L.S., Mind in Society: The Development of Higher Psychological Processes, Ed. Michael Cole et.al, Cambridge: Harvard University Press, 1978 